\title{
Monitoring Etna volcanic plumes using a scanning LiDAR
}

\author{
Simona Scollo • Antonella Boselli • Mauro Coltelli • \\ Giuseppe Leto • Gianluca Pisani • Nicola Spinelli • \\ Xuan Wang
}

Received: 5 April 2012 /Accepted: 24 September 2012 /Published online: 9 November 2012

(C) Springer-Verlag Berlin Heidelberg 2012

\begin{abstract}
In this paper, we use data obtained from LiDAR measurements during an ash emission event on 15 November 2010 at Mt. Etna, in Italy, in order to evaluate the spatial distribution of volcanic ash in the atmosphere. A scanning LiDAR system, located at $7 \mathrm{~km}$ distance from the summit craters, was directed toward the volcanic vents and moved in azimuth and elevation to analyse different volcanic plume sections. During the measurements, ash emission from the North East Crater and high degassing from the Bocca Nuova Crater were clearly visible. From our analysis we were able to: (1) evaluate the region affected by the volcanic plume presence; (2) distinguish volcanic plumes containing spherical aerosols from those having non-spherical ones; and (3) estimate the frequency of volcanic ash emissions. Moreover, the
\end{abstract}

Editorial responsibility: J. Taddeucci

S. Scollo $(\bowtie) \cdot$ M. Coltelli

Istituto Nazionale di Geofisica e Vulcanologia,

Osservatorio Etneo, Sezione di Catania,

Piazza Roma 2, 95123 Catania, Italy

e-mail: simona.scollo@ct.ingv.it

A. Boselli

CNISM and IMAA-CNR,

C.da S. Loja, 85050 Tito Scalo, Potenza, Italy

G. Leto

Osservatorio Astrofisico di Catania, INAF,

Via Santa Sofia 78, I-95123 Catania, Italy

G. Pisani $\cdot$ N. Spinelli

CNISM and Dipartimento di Scienze Fisiche, Università di Napoli "Federico II",

via Cintia 21, 80126 Napoli, Italy

X. Wang

CNISM and CNR-SPIN, Dipartimento di Scienze Fisiche, Università di Napoli "Federico II",

via Cintia 21, 80126 Napoli, Italy spatial distribution of ash mass concentration was evaluated with an uncertainty of about $50 \%$. We found that, even during ash emission episodes characterised by low intensity like the 15 November 2010 event, the region in proximity of the summit craters should be avoided by air traffic operations, the ash concentration being greater than $4 \times 10^{-3} \mathrm{~g} / \mathrm{m}^{3}$. The use of a scanning permanent LiDAR station may usefully monitor the volcanic activity and help to drastically reduce the risks to aviation operations during the frequent Etna eruptions.

Keywords Volcanic plume - Scanning LiDAR measurements $\cdot$ Etna $\cdot$ Ash emission episodes

\section{Introduction}

During explosive activity, volcanoes release a large amount of silicate particles and gases mainly composed of water vapour, carbon and sulphur dioxides (Sparks et al. 1997). This emission represents the most important natural source of pollutants in the atmosphere (Oppenheimer 2003), affects terrestrial ecosystems and human health on local to regional scales (e.g. Mather et al. 2003) and influences microphysical processes in clouds and climate (Durant et al. 2010). Silicate particles, in particular, cause respiratory problems, eye injuries and skin irritations (e.g. Horwell and Baxter 2006), damage to crops, roads and infrastructures (e.g. Blong 1984), whereas sulphur dioxide leads to acid rain, lowers the surface temperatures and, if the stratosphere is reached, promotes depletion of the Earth's ozone layer (e.g. Robock 2000). An accurate monitoring of the amount of volcanic aerosol ejected in atmosphere is, hence, necessary.

Etna is one of the most active volcanoes in the world and is considered among those volcanoes frequently causing damage to airport operations (Guffanti et al. 2008), especially due to the high frequency of explosive activity (e.g. 
Branca and Del Carlo 2005). In order to reduce the impact of volcanic plumes on aviation and the local population, since 2000 the Istituto Nazionale di Geofisica e Vulcanologia, Osservartorio Etneo (INGV-OE) has developed an alert system based on tremor thresholds (e.g. Alparone et al. 2007). Moreover, since 2006, the system has been improved thanks to the use of new instruments able to detect the tephra fallout and eruptive clouds, together with better volcanic ash transport and dispersal models (Scollo et al. 2009). Monitoring is currently based on multispectral infrared measurements by the Spin Enhanced Visible and Infrared Imager on board the Meteosat Second Generation geosynchronous satellite (SEVIRI), visual and thermal cameras and three radar disdrometers. In general, satellite-based sensors are available with different spatial and temporal resolutions over a range of different wavelengths (see Thomas and Watson 2010 for a review) and are able to retrieve volcanic emissions using appropriate algorithms. For example, the ash plume optical thickness, the particle effective radius and the total mass may be evaluated applying the brightness temperature difference procedure (e.g. Corradini et al. 2010; Prata 1989). Data from visual and thermal cameras provides useful information on eruptive phenomena (Andò and Pecora 2006) allowing detection of ash-rich eruptive columns and distinction of explosive from effusive activity (e.g. Behncke et al. 2009). Finally, three continuous wave X-band disdrometers that measure the terminal settling velocity of volcanic particles falling above the radar (Scollo et al. 2005), detect the ash fall rate. However, these instruments may fail under adverse conditions (e.g. low-intensity eruption plumes) and, moreover, each instrument has limits and employs specific assumptions (e.g. see Bonadonna et al. 2012). Consequently, an efficient monitoring system of volcanic ash plumes can be carried out only by using a combination of different measurement techniques.

Since the first observations of airborne volcanic ash layers in the 1990s (Barton et al. 1992; Defoor et al. 1992), measurements from light detection and ranging technology (LiDAR) have improved our knowledge on volcanic ash aerosols released during explosive eruptions. Volcanic plumes emitted during the 2001 and 2002 Etna eruptions were detected by the EARLINET network far from the volcanic source. For these events, volcanic ash layers were measured through a combined Raman-elastic backscatter LiDAR (Pappalardo et al. 2004; Wang et al. 2008). During Etna strombolian activity in July 2008 LiDAR measurements of the volcanic plume were performed at about $10 \mathrm{~km}$ east of the main craters by Fiorani et al (2009). Several LiDAR measurements were carried out on the Eyjafjallajokull volcanic plume in April 2010 (e.g. Ansmann et al. 2010; Carstea et al. 2010; Sicard et al. 2012) which enabled testing the ability of a LiDAR system to detect volcanic ash (Ansmann et al. 2010; Colette et al. 2010). LiDAR measurements of the atmosphere may detect aerosol layers and, under suitable conditions (e.g. no high values of the cloud optical depth), may estimate the column height. This parameter is one of the key elements needed to reliably forecast plume dispersal using volcanic ash transport and dispersal models (e.g. Folch et al. 2008) because from its correct estimation the mass eruption rate (e.g. Carey and Sparks 1986) and the volcanic explosive index (Newhall and Self 1982) may be evaluated. From LiDAR measurements we can detect the position of volcanic plumes in the atmosphere and map ash mass concentrations, though with a certain degree of uncertainty. Furthermore, the polarisation LiDAR instrument is particularly suited to distinguishing spherical particles from non-spherical ones (Winker and Osborn 1992; Sassen 2005; Sassen et al. 2007).

In this paper, we support use of a scanning LiDAR system as a new tool for monitoring explosive activity at Etna. On 15 November 2010, a scanning polarisation LiDAR was tested near the summit craters. Compared to previous LiDAR measurements applied to volcanic plumes, the ability to direct the laser beam in any point of the space provides information on the plume particles' spatial distribution. While a detailed optical investigation of the volcanic aerosol properties of this event has recently been performed (Pisani et al. 2012), in this paper, we focus on the ash dispersal process and on mapping estimated mass concentrations of ash in the plume during the activity of 15 November 2010 when ash emission was erupted from NEC for the entire day and form a very dilute volcanic plume. The manuscript is set out as follows: in "The 14-15 November 2010 ash emission episodes", we describe the volcanological features of the event; in "Instrumentation and facilities" and "Method", we briefly describe the LiDAR system, the instrument facility and show the methodology used in the data acquisition and analysis and, finally, in "LiDAR observations", we discuss the hazard from such events and the advantages of having a permanent LiDAR near an active volcano.

\section{The 14-15 November 2010 ash emission episodes}

Mt. Etna is considered one of the most active volcanoes in the world for its frequent eruptions and for its permanent degassing plume. Explosive activity comes from the central craters (Fig. 1) made up of the Bocca Nuova Crater (BNC), the North East Crater (NEC) and the South East Crater (SEC), recently shifted to a new vent informally named New South East Crater (NSEC; e.g. The 23 April 2012 paroxysm of Etna in www.ct.ingv.it), or from fractures opened on the volcanic flanks. After the eruption occurring in 2008-2009 (e.g. Di Grazia et al. 2009), Etna entered into an almost dormant phase until April 2010, when on 8 April there was ash emission from the pit crater at the base of SEC (NSEC) and a volcanic plume rose up to $1 \mathrm{~km}$ above the vent and lasted less than $1 \mathrm{~h}$ (Corsaro 2010). Since this 
Fig. 1 a Map of the central craters of Etna volcano: North East Crater (NEC), Bocca Nuova $(B N)$ and South East Crater (SEC), $A O$ indicates the LiDAR station; b volcanic plume photographed during the LiDAR measurements at the AO station (photo taken from $\mathrm{S}$. Scollo)
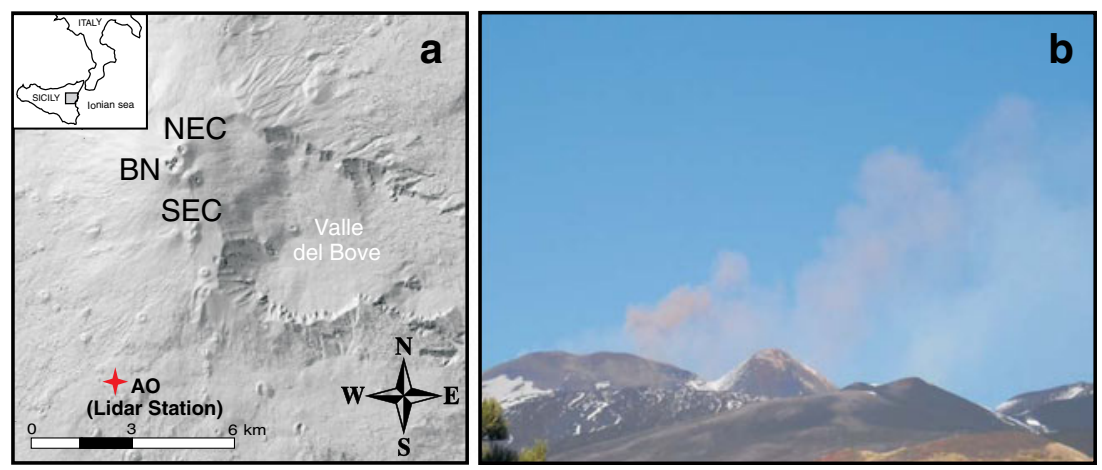

event, several ash emission episodes (e.g. Andronico et al. 2009) have occurred from the summit craters (Table 1).
In this paper, we focus on the November activity when the LiDAR measurements were performed. During this month,

Table 1 Date, time, volcanic vent, eruptive style and features of the plume dispersal and fallout of the main explosive events in 2009 and 2010

\begin{tabular}{|c|c|c|c|c|}
\hline Date & Time (UTC) & Volcanic vent & Eruptive style & Features of the plume dispersal and fallout \\
\hline $\begin{array}{r}6 / 03 / 2009 \text { to } \\
15 / 03 / 2009\end{array}$ & All the day & $\begin{array}{l}\text { Eruptive fissure } \\
\text { at } 2,800 \text { ma.s.l. }\end{array}$ & $\begin{array}{l}\text { Ash emission episodes } \\
\text { and strombolian activity }\end{array}$ & $\begin{array}{l}\text { Few hundred meters } \\
\text { Tephra fallout only in the proximal area }\end{array}$ \\
\hline $28 / 06 / 2009$ & Since $5: 14$ & $\mathrm{BN}$ & Ash emission episodes & $\begin{array}{l}\text { Very dilute plume toward E and SE } \\
\text { No tephra fallout }\end{array}$ \\
\hline $18-19 / 11 / 2009$ & All the day & $\begin{array}{l}\text { Eruptive fissure } \\
\text { on the east flank of SEC }\end{array}$ & Ash emission episodes & $\begin{array}{l}\text { Very dilute volcanic plume toward E } \\
\text { No tephra fallout }\end{array}$ \\
\hline $8 / 04 / 2010$ & $17: 51$ & NSEC & Ash emission episode & $\begin{array}{l}1 \mathrm{~km} \text { above the plume toward NE } \\
\text { Fallout only in the proximal area }\end{array}$ \\
\hline $7 / 05 / 2010$ & $11: 04$ & NSEC & Ash emission episode & $\begin{array}{l}\text { Few hundred meters above the vent } \\
\text { No tephra fallout }\end{array}$ \\
\hline $8 / 06 / 2010$ & $4: 22$ and $4: 52$ & NSEC & Ash emission episodes & $\begin{array}{l}\text { Few hundred meters above the vent } \\
\text { No tephra fallout }\end{array}$ \\
\hline $25-29 / 08 / 2010$ & 13:05 & $\mathrm{BNC}$ & Ash emission episodes & $\begin{array}{l}\text { The greatest event occurred on } 25 \text { August } \\
\text { The plume reached } 1-2 \mathrm{~km} \text { above the vent } \\
\text { Plume direction and fallout toward E }\end{array}$ \\
\hline $4-5 / 09 / 2010$ & 13:01 & $\mathrm{BNC}$ & Ash emission episodes & $\begin{array}{l}\text { Few hundred meters above the vent } \\
\text { No tephra fallout }\end{array}$ \\
\hline $22 / 09 / 2010$ & $22: 42$ & $\mathrm{BNC}$ & Ash emission episode & $\begin{array}{l}\text { Few hundred meters above the vent } \\
\text { No tephra fallout }\end{array}$ \\
\hline $17 / 09 / 2010$ & $7: 55$ & $\mathrm{BNC}$ & Ash emission episode & $\begin{array}{l}\text { Few hundred meters above the vent } \\
\text { No tephra fallout }\end{array}$ \\
\hline $17 / 09 / 2010$ & $9: 30$ & NSEC & Ash emission episode & $\begin{array}{l}\text { Intracrateric collapse } \\
\text { No tephra fallout }\end{array}$ \\
\hline $7-9 / 10 / 2010$ & $10: 27$ & $\mathrm{BNC}$ & Ash emission episodes & $\begin{array}{l}\text { The greatest occurred on } 7 \text { October formed } \\
\text { a discontinuous tephra deposit reaching } \\
\text { Rifugio Sapienza }\end{array}$ \\
\hline $31 / 10 / 2010$ & $15: 33$ & $\mathrm{BNC}$ & Ash emission episode & $\begin{array}{l}\text { Few hundred meters } \\
\text { No tephra fallout }\end{array}$ \\
\hline $12-15 / 11 / 2010$ & All the day & NEC & Ash emission episodes & $\begin{array}{l}\text { Continuous ash emission activity } \\
\text { Volcanic plume spanning from } \mathrm{S} \text { to NE } \\
\text { Tephra fallout only in the proximal area }\end{array}$ \\
\hline $22 / 12 / 2010$ & $4: 46$ & $\mathrm{BNC}$ & Ash emission episode & $\begin{array}{l}\text { Volcanic plume toward NE } \\
\text { Tephra fallout reached the Linguaglossa' tov }\end{array}$ \\
\hline
\end{tabular}

Data are taken from multidisciplinary reports published by INGV-OE (www.ct.ingv.it) 
there was an increase of the activity in NEC crater. Emissions of water vapour and ash, occurring every 1-2 min, were observed on 12 November by volcanologists during a field survey at the summit craters (Behncke, personal communication). A marked increase of ash emission was detected in the morning of 14 November when a very diluted plume was dispersed toward the SW direction. The activity proceeded on 15 November 2010 and formed a thin ash plume which blew toward the E and SE in the morning and shifted toward the NE in the afternoon. Videos of 15 November 2010 from the camera (EMOV) located at the Montagnola site on the SE volcano flank and less than $5 \mathrm{~km}$ away from summit craters showed that ash emission episodes from the NEC were pulsating. Highest intensity of explosions was recorded early morning before the LiDAR measurements and after 14:00 UTC (Fig. 2a, b). Volcanologists at the edge of NEC reported a fairly modest and intermittent ash emission from this crater and degassing from BNC and NSEC (Behncke et al. 2010). Sometimes, ash due to crumbling walls from BNC was also observed (Behncke et al. 2010). The coarser particles settled on the edge of the crater and formed a thin layer on the upper part of the volcano. A tephra sample, analysed by Andronico et al. (2012), presented a coarse grained distribution with
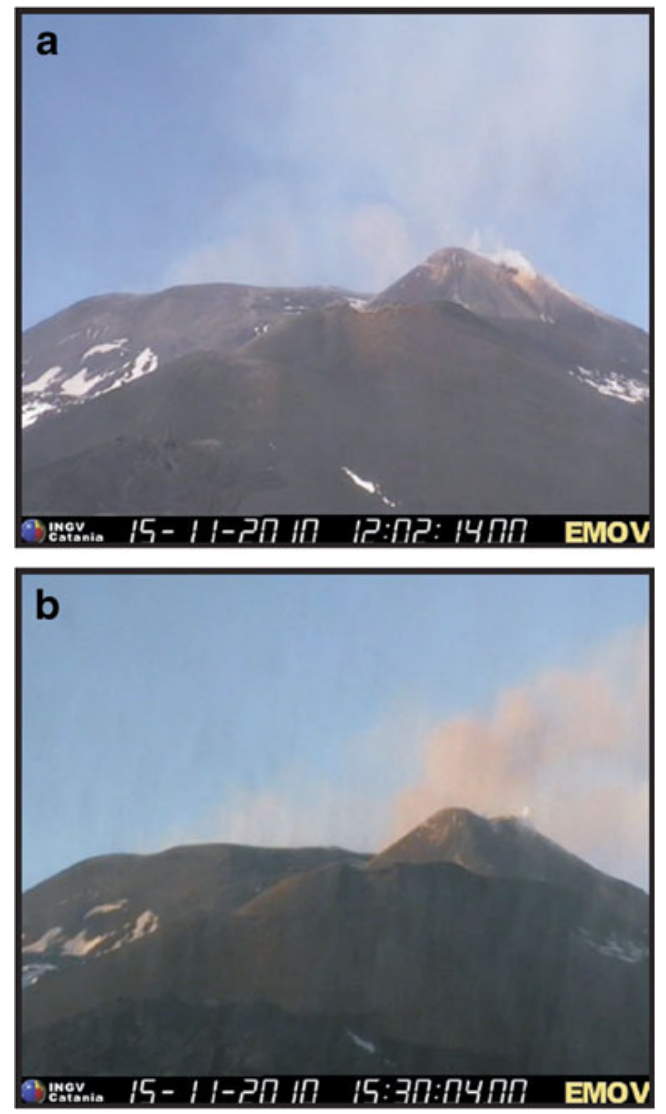

Fig. 2 Ash emission from the NEC recorded by the EMOV camera located on the SE flank at $5 \mathrm{~km}$ away from the volcanic vent at a 12:02; b 15:30 UTC particles having a mode of $0.25 \mathrm{~mm}$ and a small percentage ( $<5 \%$ ) of particles of sizes $<0.063 \mathrm{~mm}$. Authors showed that particles were mainly juvenile clasts, with a high percentage of tachylites, followed by lithic fragments and crystals and had peculiar morphologies with tachylites of blocky morphology. The emissions continued up to the morning of 16 November when the eruptive activity ended.

\section{Instrumentation and facilities}

The LiDAR system named "VAMP" (Volcanic Ash Monitoring by Polarisation) makes use of a frequency doubled $\mathrm{Nd}$ :YAG laser source operating at a 532-nm wavelength, with a repetition rate of $1 \mathrm{kHz}$. Laser pulses are emitted with energy of $0.3 \mathrm{~mJ}$, duration of $40 \mathrm{~ns}$ and linear polarisation better than 100:1. The receiver is a $20 \mathrm{~cm}$ diameter Cassegrain telescope with a focal length of $140 \mathrm{~cm}$. A filter (central wavelength, $532 \mathrm{~nm}$; full width at half maximum, $0.5 \mathrm{~nm}$ ) is used for the spectral selection. The system transmits a linearly polarised laser light and parallel and crosspolarised components of the backscattered radiation are collected separately. During the night, due to the lower background signal, an integration time of $20 \mathrm{~s}$ is required to obtain LiDAR profiles reaching $20 \mathrm{~km}$, while $1 \mathrm{~min}$ of integration time is necessary to reach $10 \mathrm{~km}$ in daytime measurements. This means that these are the time scales of the observable evolution. For these ranges and integration time, the system acquires data with a spatial resolution of $30 \mathrm{~m}$ along the line of sight. A further integration of data over 60 or $180 \mathrm{~m}$ is performed during data analysis in order to enhance the signal to noise ratio. The VAMP system is mounted on a bi-axial motorised fork and may be moved in azimuth and elevation with the possibility to scan the volcanic plume either horizontally and/or vertically at a maximum speed of $0.1 \mathrm{rad} / \mathrm{s}$. The calibration of the VAMP system and a detailed description of the apparatus are reported in Pisani et al. (2012). The VAMP system was installed at the "M.G. Fracastoro" astrophysical observatory $\left(14.97^{\circ} \mathrm{E}, 37.69^{\circ} \mathrm{N}\right)$ of the Istituto Nazionale di Astrofisica in Catania, hereafter named AO (Fig. 1a). Choosing a suitable location to carry out LiDAR measurements near an active volcano is fundamental because: LiDAR measurements should be performed each time an eruption occurs and continuous measurements might be required in case of long-lived explosive activity; positioning the LiDAR along the plume dispersal axis should be avoided since the system can be seriously damaged by ash fallout. The AO location has several advantages: (1) the observatory is located at $1,760 \mathrm{~m}$ on the SW flank of the volcano, only $7 \mathrm{~km}$ away from the Etna summit craters, allowing the laser beam to scan the atmosphere nearly the source (Fig. 1b); (2) AO has the necessary facilities to perform long-lived measurement 
campaigns and (3) the location is suitable to perform measurements during most of the eruptive events; indeed, the volcanic plume affects the SE sector because winds mainly blow toward the E and SE (Barsotti et al. 2010). In general, LiDAR measurements cannot be performed in cloudy weather conditions. It has been statistically evaluated that clouds prevent astronomical observations at the AO about $30 \%$ of the time (http://sln.oact.inaf.it/index.php/it/informazioni-generali/ meteorologia-e-statistiche.html); consequently, a LiDAR system at the AO can probably achieve $70 \%$ of sampling efficiency. In addition, the facilities that are available and the presence of locally based personnel make the AO station an optimum position for a permanent LiDAR station.

\section{Method}

The VAMP LiDAR system detects the back-scattered radiation at the laser wavelength $\lambda$. Analysing this signal, we obtain the aerosol backscattering coefficient $\left(\beta_{\text {aer }}\right)$. The aerosol backscatter coefficient is an optical parameter which is proportional to the strength of the LiDAR signal and describes how much the light is scattered in the backward direction. Its value depends on the type (dimension, composition and shape) and concentration of particulate in the atmospheric sounded sample (Wandinger 2005). For the LiDAR and the VAMP system, based on elastic scattering only the aerosol backscattering coefficient is evaluated using the Klett-Fernald algorithm (Fernald 1984; Klett 1985). This procedure requires knowledge of the LiDAR ratio (LR), an essential parameter in aerosol optical characterisation since it is related to the aerosol microphysical properties such as chemical composition, refractive index, shape and particle size distribution (Ackermann 1998) but it is independent on concentration. The LR of the volcanic plume used in our data analysis has been evaluated by taking advantage of the fact that the atmospheric region before and after the plume can be considered aerosol free. The resulting values of LR ranged between 30 and $45 \mathrm{sr}$ (Pisani et al. 2012). Using the polarisation LiDAR technique and analysing the two components of the backscatter radiation, parallel and cross-polarised with respect to the polarisation plane of the emitted laser beam, the total volume depolarization ratio $(\delta)$ and the aerosol linear depolarization $\left(\delta_{\text {aer }}\right)$ are evaluated (Winker and Osborn 1992; Sassen 2005; Sassen et al. 2007). The aerosol linear depolarization allows to distinguish spherical aerosol (liquid droplets) from nonspherical ones (volcanic ash) in the plume. Indeed, irregularshaped aerosols produce higher values of $\delta_{\text {aer }}$ with respect to spherical particles such us water, volcanic sulphuric acid

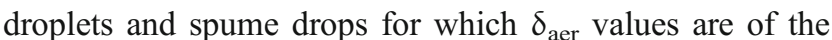
order of few percent (Sassen 2005). LiDAR technique allows to measure the optical parameters of the atmospheric particles along the laser beam path, with a spatial (longitudinal) resolution as a function of the signal to noise ratio (60 and $180 \mathrm{~m}$ in our case); this is also the spatial resolution with which the sampled atmospheric regions with different optical properties can be characterised. Moreover, in a single measurement, a LiDAR samples the volume of the atmosphere that can be easily evaluated by taking into account the divergence of the beam, the distance of the atmospheric target and the longitudinal resolution of data. In our case (divergence $0.2 \mathrm{mrad}$, distance about $7 \mathrm{~km}$, spatial resolution 60-180 m), the transversal and longitudinal dimension of the sampled volume over the crater are of the order of $1.5 \mathrm{~m}$ and $60-180 \mathrm{~m}$, respectively.

Finally, from the backscattering and depolarization coefficients, it is possible to evaluate the volcanic ash concentration. An exhaustive description of the methodology used is reported in the work of Pisani et al. (2012). In particular, ash mass concentration is evaluated by means of the expression:

$c=k \times L R \times \rho \times \beta_{a}$

where $k$ is the ash conversion factor which is function of the particle size distribution and, for large values of the effective radius, $r_{\text {eff }}$, it is given by $2 r_{\text {eff }} / 3$ (Schumann et al. 2011; Gasteiger et al. 2011). Pisani et al. (2012) assumed a value of about $10 \mu \mathrm{m}$ for $r_{\text {eff }}$ and $k$ is hence set to $0.6 \times 10^{-5} \mathrm{~m}$; LR is the mean value of the estimated LiDAR ratio (Pisani et al. 2012), $\rho$ is the density of volcanic ash fixed to $2,450 \mathrm{~kg} / \mathrm{m}^{3}$ (Scollo et al. 2005), and $\beta_{a}$ is the volcanic ash backscatter coefficient. Its value is obtained following the approach applied by Tesche et al. (2009):

$\beta_{a}=\beta_{a e r} \frac{\left(\delta_{a e r}-\delta_{n a}\right)\left(1+\delta_{a}\right)}{\left(\delta_{a}-\delta_{n a}\right)\left(1+\delta_{a e r}\right)}$

where $\beta_{\text {aer }}$ and $\delta_{\text {aer }}$ values come directly from our measurements $\left(\delta_{\text {na }}\right.$ is set to $0.01, \delta_{\mathrm{a}}$ is set to 0.5$)$. The errors on ash mass concentration are evaluated from the uncertainties of LR, $\beta_{\mathrm{a}}$ and $\rho$ and reach a value of $25 \%$. An additional uncertainty of about $50 \%$ must be considered due to the assumption of the effective radius (Pisani et al. 2012).

\section{LiDAR observations}

LiDAR measurements carried out at the AO station on 15 November are summarised in Table 2. In the first two measurements (M1 and $M 2$ ), the laser beam was directed toward the zenith to verify the functionality of the system and for calibration purposes (Pisani et al. 2012). At 12:38 UTC, the LiDAR beam was directed towards the ash emission and elevation and azimuth were changed during the measurements in order to scan the volcanic plume (M3 in Table 1). Figure 3 shows $\beta_{\text {aer }}$ and $\delta_{\text {aer values for measurements }}$ 
Table 2 Measurements carried out at the AO station on 15 November 2010

\begin{tabular}{|c|c|c|c|c|c|c|c|}
\hline$M$ & Time (UTC) & $E\left({ }^{\circ}\right)$ & $A\left(^{\circ}\right)$ & $\Delta A\left(^{\circ}\right)$ & $\Delta T(\mathrm{~s})$ resolution & $\mathrm{Rp}$ & Type \\
\hline$M 1$ & & 90 & - & - & 60 & 10 & Zenith \\
\hline$M 2$ & & 90 & - & - & 60 & 1 & Zenith \\
\hline \multirow[t]{2}{*}{$M 3$} & $12: 38-13: 29$ & $\begin{array}{l}14.4 \\
14.65\end{array}$ & $\begin{array}{l}21.9-36.9 \\
21.9-36.9\end{array}$ & $\begin{array}{l}1 \\
1\end{array}$ & 60 & 1 & Grid \\
\hline & & 14.9 & $21.9-36.9$ & 1 & & & \\
\hline$M 4$ & $13: 45-14: 50$ & 14.4 & 17.3 & - & 30 & 1 & Fixed \\
\hline M5 & $16: 17-16: 53$ & $14.4-14.9$ & $21.9-36.9$ & 1 & 20 & 2 & Grid \\
\hline
\end{tabular}

The table shows the number of measurements $(M)$, the time in UTC, the elevation $(E)$ and azimuth $(A)$, the time resolution $(\Delta T)$ in seconds, the number of repetitions (Rp) and the type of the measurement indicating if it was performed at the zenith, in a grid (Grid) and in a fixed point (Fixed)

performed between 12:38 and 13:29 UTC. It should be noted the contribution of background aerosol load in clear sky and no aerosol conditions at the volcanic plume height is less than $\sim 10^{-7} \mathrm{sr}^{-1} \mathrm{~m}^{-1}$ in the Mediterranean region (Sicard et al. 2011), so that it may be considered negligible. LiDAR data were collected at three different elevations $\left(14.4^{\circ}, 14.65^{\circ}\right.$ and $\left.14.9^{\circ}\right)$. The volcanic plume was located between 6.5 and $7.5 \mathrm{~km}$ from the AO. In the plume region $\beta_{\text {aer }}$ reaches values larger than $2 \times 10^{-5} \mathrm{~m}^{-1} \mathrm{sr}^{-1}$ with the highest values (above $5 \times$ $10^{-5} \mathrm{~m}^{-1} \mathrm{sr}^{-1}$ ) between 6.5 and $7 \mathrm{~km}$ from the $\mathrm{AO}$ station. It is notable that higher values of $\beta_{\text {aer }}$ indicate a higher concentration of volcanic aerosols. Data of Fig. 3 show that there were two different plumes, the first one lying between 6.5 and $7.0 \mathrm{~km}$ from the LiDAR site had lower $\delta_{\text {aer }}$ values $(<5 \%)$ than the layer located between 7 and $7.5 \mathrm{~km}(10-15 \%)$. This plume was mainly made up of water vapour and/or volcanic gas in liquid phase, while in the second region volcanic ash were present. In the $M 4$ measurements, the laser beam was pointed toward a fixed direction defined by azimuth angle of $17.3^{\circ}$ and elevation angle of $14.4^{\circ}$ from the $\mathrm{N}$ direction, corresponding approximately to $250-300 \mathrm{~m}$ of altitude above summit craters. Figure 4 shows the time evolution of the particle backscattering and the linear volume depolarization $\delta_{\text {aer }}$ as measured between 13:45 and 14:50 UTC. Data again show two plumes, one mainly made up of volcanic ash (values of the depolarization up to $30 \%$ ) between 6.5 and $7 \mathrm{~km}$ and the other of water vapour and/or gas non-depolarizing particles (droplets; values of depolarization lower than $2 \%$ ) between 6 and $6.5 \mathrm{~km}$. This figure clearly shows that volcanic ash emission was unsteady. In particular, a disappearance of the NEC emission from 14:16 to 14:23 UTC is evident. Analysing the number of explosions between 13:45 and 14:22 UTC in the EMOV videos, we observed a drop in the ash emission episodes between 14:12 and 14:22 UTC. Explosions occurred every $2.5 \mathrm{~min}$ with respect to $1.5 \mathrm{~min}$ retrieved between 13:45 and 14:12 UTC and between 14:22 and 14:45 UTC. In Fig. 5, the scatter plot of the integrated backscattering of the two plumes is reported. The backscatter coefficient integrated in each layer highlights a negative correlation between the two plumes, whose correlation coefficient has larger values $(R=0.72)$ between $13: 58$ and 14:24 UTC (Fig. 5). Figure 6 shows results of the scanning of the volcanic plume, directed toward the NE direction, carried out by LiDAR at 16:17 UTC. For these measurements, the integration time was reduced to $20 \mathrm{~s}$, because of the higher signal to noise ratio of the measurements performed in night time conditions. Higher depolarization values (of the order of $40 \%$ ) are detected at higher levels above the volcanic vent. Moreover, the plume from BNC, mainly made up of non-polarizing particles, had a greater percentage of polarizing irregularly shaped particles in the afternoon with respect to the morning.

Figure 7 shows ash mass concentration maps for $M 3$ and $M 5$ measurements (Figs. 3 and 6). Ash concentration layers of $2 \times$ $10^{-3} \mathrm{~g} / \mathrm{m}^{3}, 3 \times 10^{-3} \mathrm{~g} / \mathrm{m}^{3}$ and $4 \times 10^{-3} \mathrm{~g} / \mathrm{m}^{3}$ were chosen because they help to identify the area of low, medium and high contamination defined by the International Civil Aviation Organisation (ICAO) in the Volcanic Ash Contingency Plan in July 2010 as the airspace where volcanic ash may be encountered at concentrations equal to or less than $2 \times 10^{-3} \mathrm{~g} / \mathrm{m}^{3}$, greater than $2 \times 10^{-3} \mathrm{~g} / \mathrm{m}^{3}$, but less than $4 \times 10^{-3} \mathrm{~g} / \mathrm{m}^{3}$ and greater than $4 \times$ $10^{-3} \mathrm{~g} / \mathrm{m}^{3}$. We found that ash concentration values in the morning were lower than the values found in the afternoon, confirming an increase of the eruptive activity. The figure clearly shows that, even during low-intensity ash emission events such as the one on 15 November, 2010, there are regions in the atmosphere, around the summit craters, in which the contaminant density exceeds the thresholds defined by ICAO.

\section{Discussion}

In this paper, we have shown how the use of a scanning elastic LiDAR may reveal interesting features of volcanic plume dispersal during explosive activities of volcanoes such as Etna. We tested the capability of a LiDAR apparatus installed at a location (the Catania Astrophysical Observatory) only $7 \mathrm{~km}$ away from the volcanic vent, during the ash emission event occurring on 15 November 2010. From the 
Fig. 3 Particle backscattering $\left(\mathrm{m}^{-1} \mathrm{sr}^{-1}\right)$ and depolarization profiles (\%) of $M 3$ (Table 1) at three different elevations above the summit craters: $\mathbf{a}$ and $\mathbf{b}$ at $\sim 300 \mathrm{~m}$; $\mathbf{c}$ and $\mathbf{d}$ at $\sim 400 \mathrm{~m}$; e and $\mathbf{f}$ at $\sim 500 \mathrm{~m}$. The AO station is indicated with the black dot. $P 1$ and $P 2$ indicate the BNC and NEC plumes, respectively
ParticleBackscatter $\left(\mathrm{m}^{-1} \mathrm{sr}^{-1}\right)$
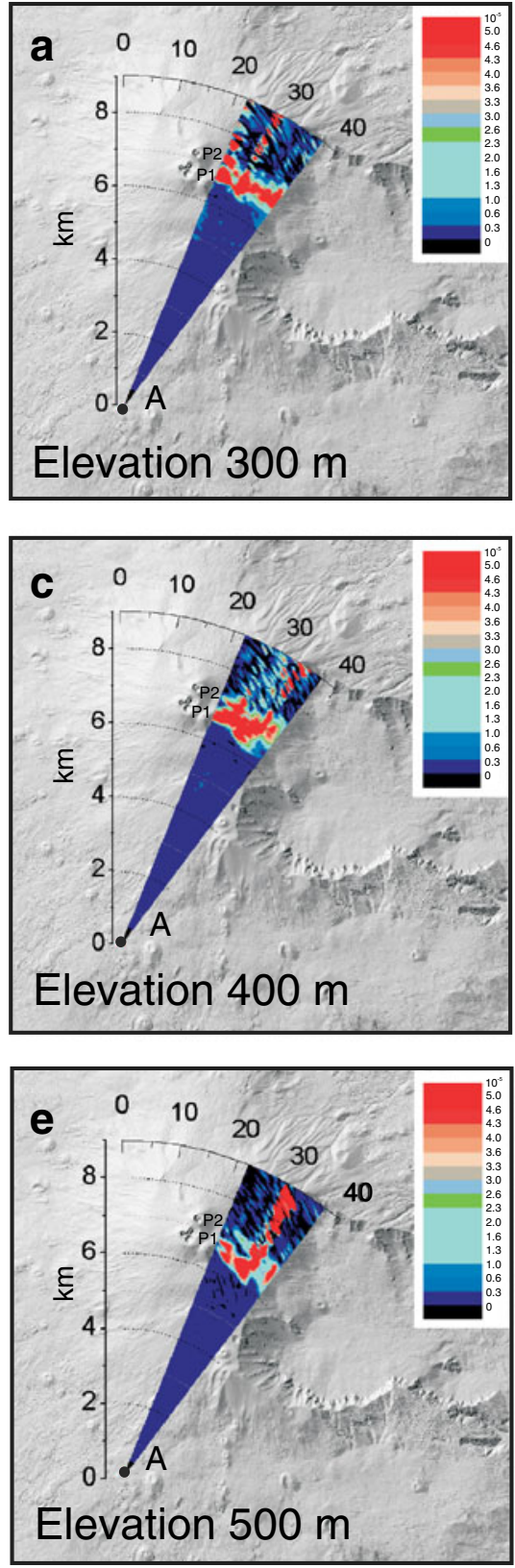

Depolarization (\%)
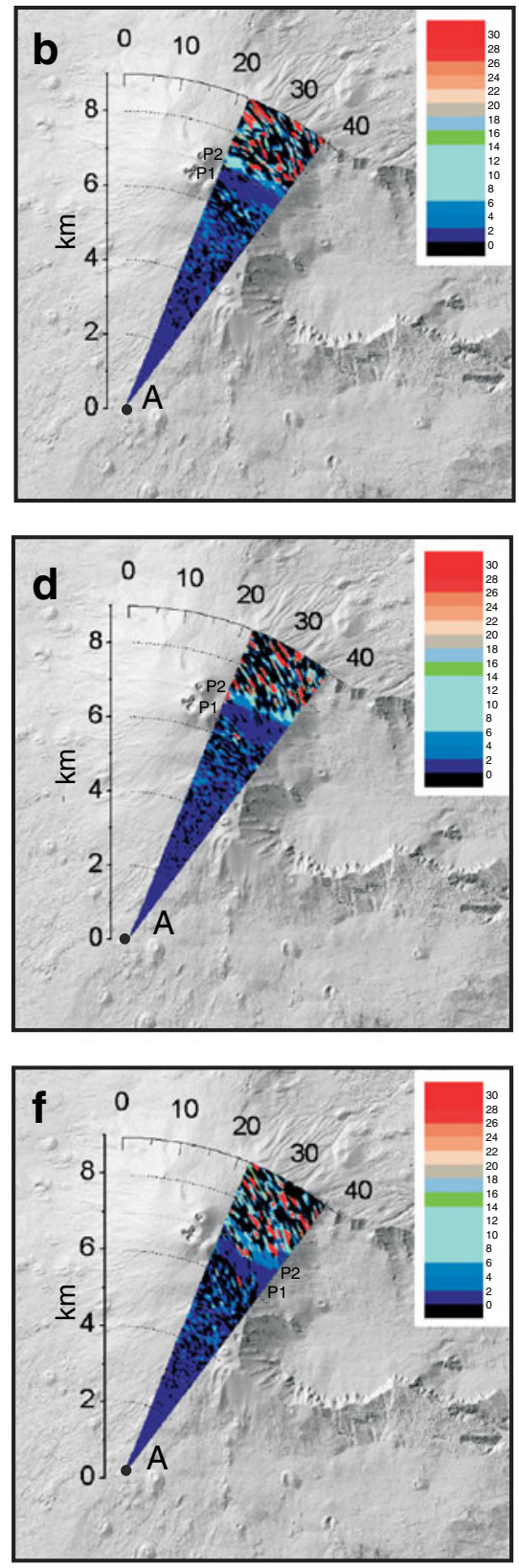

analysis of these measurements we were able to: (1) evaluate the region where volcanic ash was present; (2) distinguish volcanic ash from water and/or sulphate aerosol; (3) measure the time variation of explosive activity and (4) evaluate the mass concentrations of ash in the atmosphere.

The reconstruction of volcanic plumes in $3 \mathrm{D}$ is a challenge for the analysis of volcanic ash dispersal in the atmosphere. A powerful instrument for reconstructing the 3D structures of volcanic plumes is the radar system (e.g. Larsen et al. 1992; Lacasse et al. 2004), which, however, is very expensive and consequently its use is not very widespread. Moreover, this technique is sensitive only to larger particles (of the order $100 \mu \mathrm{m}$ to millimetres particle size) and consequently the measurements cannot capture the majority of the fine ash fraction. LiDAR systems are in contrast very promising. Since the VAMP system was pointed toward the volcanic vent during clear weather conditions and the ash emission from NEC was at the same time visible by the video surveillance system and seen by volcanologists on duty near summit craters, it was possible to correlate the measurements to volcanic ash dispersal without ambiguity. In particular, by using a very simple LiDAR with depolarisation and scanning capabilities (like the VAMP system), we are able to furnish a 3D view of the volcanic plume and 
Fig. 4 Particle backscattering and depolarization of $M 4$ (Table 2) carried out from 13:50 to 14:10 UTC. Elevation and azimuth were set at $14.4^{\circ}$ and $17.3^{\circ}$, respectively
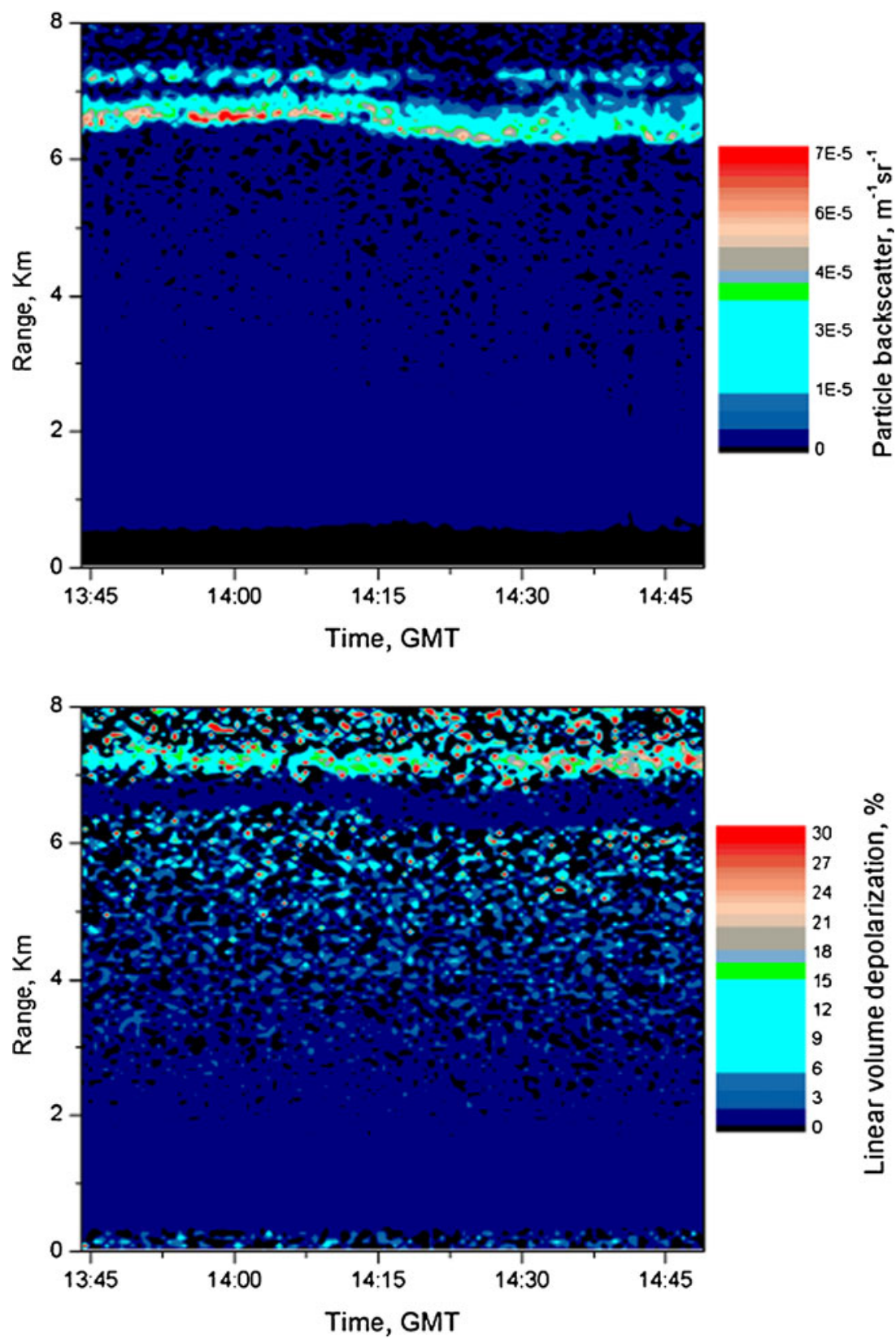

to estimate the associated ash mass concentrations, although with a degree of uncertainty. Furthermore, from LiDAR measurements shown here, two volcanic plumes with different features were clearly distinguished. One plume from NEC contained volcanic ash; the other plume from BNC was mainly made up of non-depolarizing spherical particles most likely composed of water vapour and sulphates. Recent work by Scollo et al. (2012) reported observations of the Multi-angle Imaging SpectroRadiometer for 20 volcanic plumes produced during the 2000, 2001, 2002-03, 2006 and 2008 Etna eruptions. In that paper, the authors clearly distinguished sulphate and/or water vapour-dominated volcanic plumes from ash-dominated ones. LiDAR measurements may also supply such information (e.g. Ansmann et al.
2011), which is essential to improve our understanding of the impact of volcanic plumes in the atmosphere.

Ash emission events are frequent at Mt. Etna. More than 30 episodes were recorded in 2010 alone from NEC, BNC, SEC and NSEC craters (Table 1). Analysing volcanological and seismo-acoustic observations, Spina et al. (2012) classified ash emissions in two main types: explosions from SEC and BNC were indentified as more hazardous and impulsive than events from NEC. This is also confirmed from our data analysis, which highlights that ash mass concentrations during NEC events are only likely to exceed the aviation safety thresholds at sites near the volcanic vent, and consequently these events are not very dangerous. The emission of two different plumes may be explained because 
Fig. 5 Scatterplot of the two plumes integrated backscattering and the linear best fit of the data (a) and their temporal behavior (b)
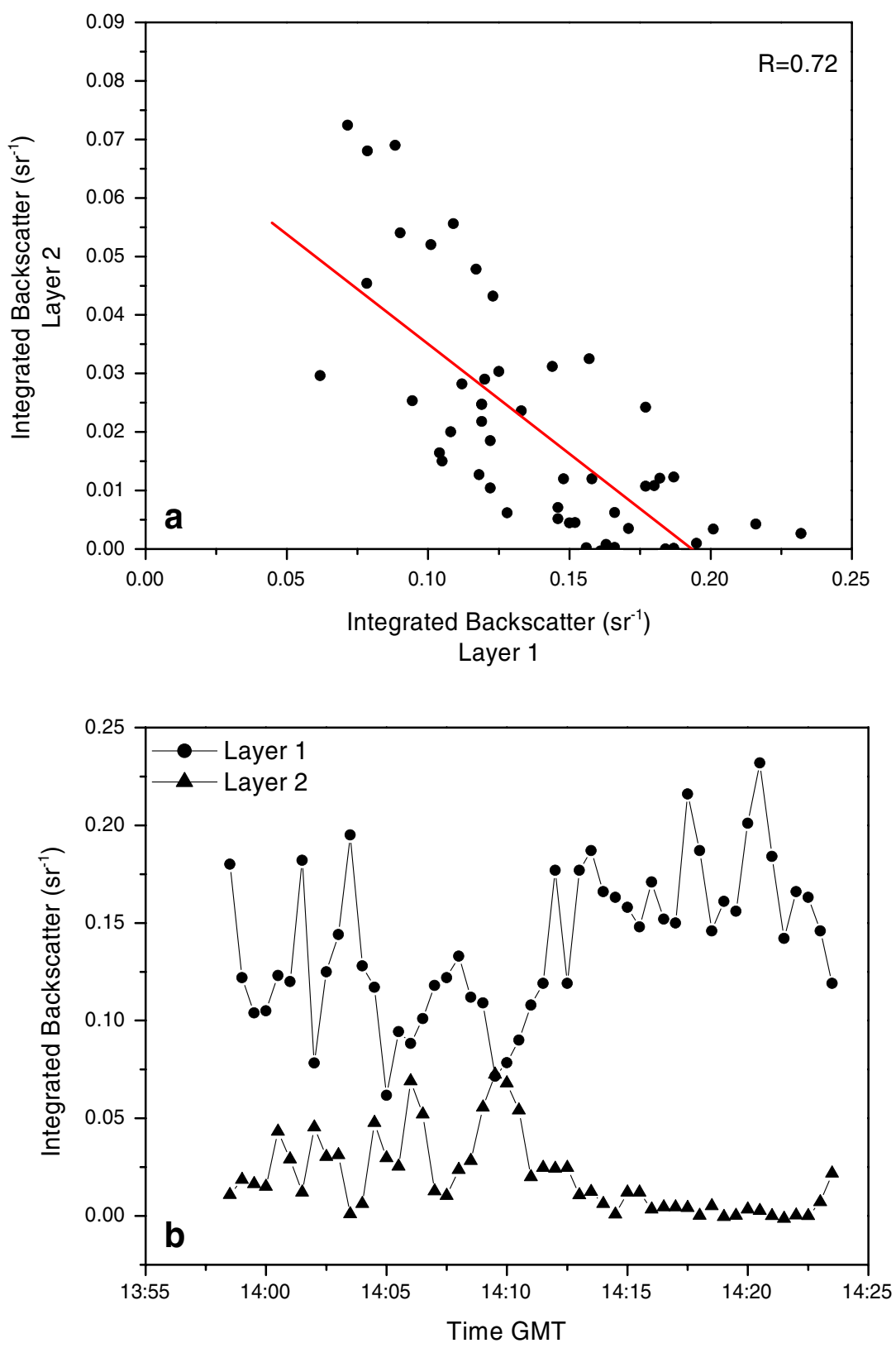

within the conduits of the summit craters distinct thermal and fluid-dynamical regimes can evolve, controlling the cooling and the crystallisation of magmas (Corsaro and Pompilio 2004). In addition, ash emission events from NEC are caused by the shifting of the volcanic tremor source centroid below the summit area between April and November 2010, in good agreement with the shifting of the explosive activity from SEC/BNC to NEC (Spina et al. 2012). However, the anti-correlation of the two plumes in the integrated backscatter signal shows some kind of interconnection from two different volcanic vents. We note that the summit crater consisted of a single crater named the Central Crater. Some important structural and morphological changes occurred in the twentieth century with the formation of NEC in 1911 as a pit on the northeastern flank of the summit cone, of BNC in 1968 as a pit crater on the west side of the Central Crater, that began to be known as Voragine (VOR). Finally, in 1971, a new pit opened on the southeast of BNC and began to be active in 1978 when a new crater named SEC was formed (Branca and Del Carlo 2005). It is hence possible that there is a connection among these different craters as suggested by Chester et al. (1985), who described the deep part of the conduit of the summit craters as an approximately cylindrical cross-section, while in the upper region there are open passages that lead to the three craters (NEC, BNC and SEC at the time of the Chester' paper).

The ability of a LiDAR system to detect volcanic ash plumes and to reliably estimate the ash mass concentration 
Fig. 6 Particle backscattering $\left(\mathrm{m}^{-1} \mathrm{sr}^{-1}\right)$ and depolarization profiles (\%) of M5 (Table 2) at three different elevations: $\mathbf{a}$ and $\mathbf{b}$ at $\sim 300 \mathrm{~m}$; $\mathbf{c}$ and $\mathbf{d}$ at $\sim 400 \mathrm{~m}$; e and $\mathbf{f}$ at $\sim 500 \mathrm{~m}$. The AO station is indicated with the black dot. $P 1$ and $P 2$ indicate the BNC and NEC plumes, respectively

\section{ParticleBackscatter $\left(\mathrm{m}^{-1} \mathrm{sr}^{-1}\right)$}
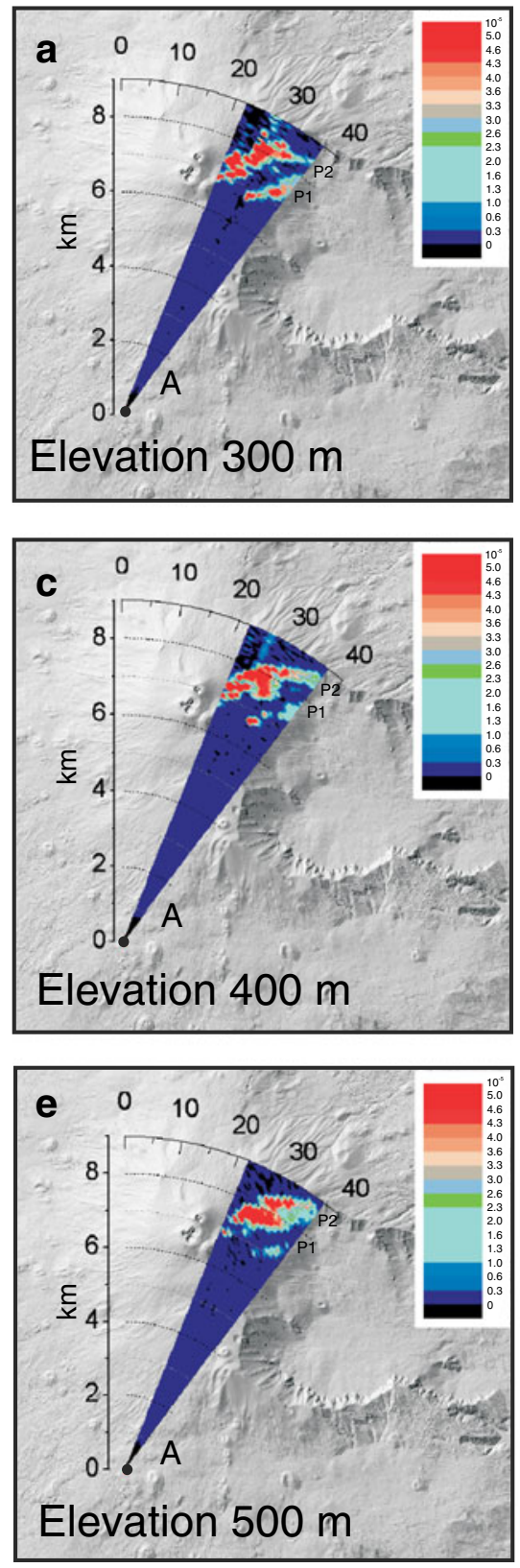

\section{Depolarization (\%)}
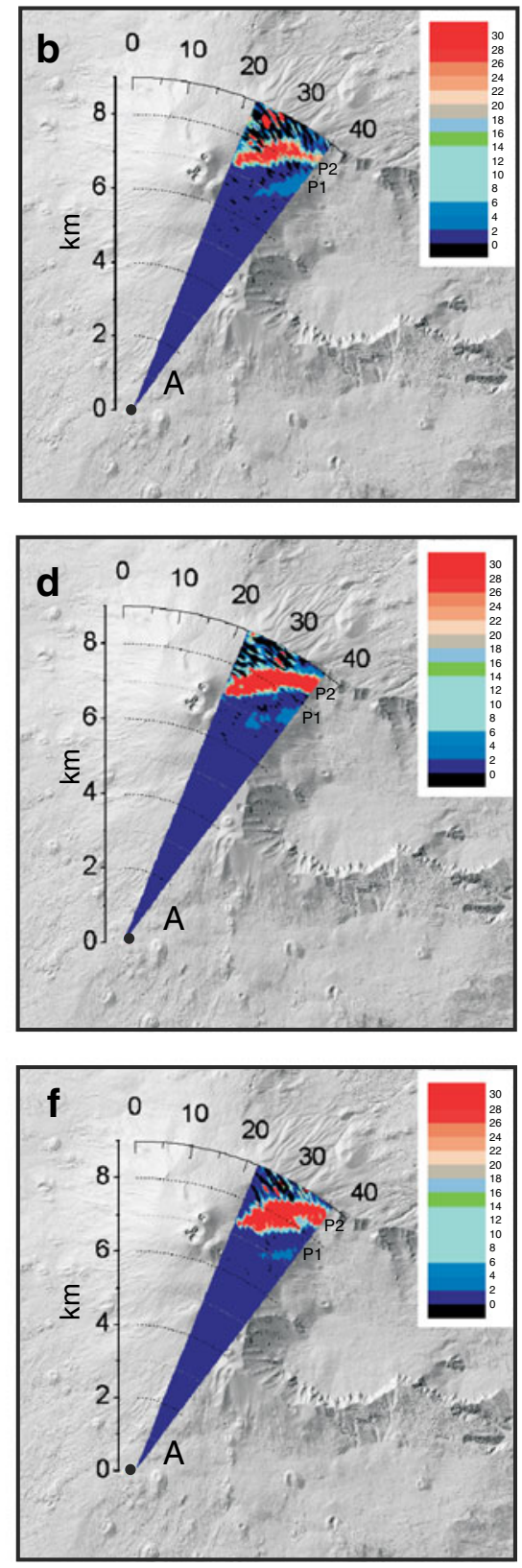

depends on the instrumental characteristics and of the type of explosive activity. For LiDAR, similarly to the VAMP system that detects only the elastic back-scattered radiation, the evaluation of the aerosol backscattering and total volume depolarization coefficients may be carried out if the LiDAR signal is still present after the volcanic ash plume crossing. In this case, in fact, under certain assumptions of LR, the Klett-Fernarld algorithm may be applied (Pisani et al. 2012). For events similar to 15 November 2010, the VAMP system may hence give useful information. However, for high optical depth volcanic plumes, this condition could not occur. Nevertheless, the scanning capability give us the opportunity to direct the laser beam toward those regions where the LiDAR equation can be solved increasing in this way the benefits of these systems. This allows us to at least outline the area of high contamination. The VAMP system can distinguish spherical particles from non-spherical particles but it could not distinguish volcanic ash from, for example, Saharan dust. For Etna, where there is an already existing and advanced monitoring system, and the presence of explosive activity is already established, so an accurate analysis of LR and depolarisation could clearly identify volcanic ash plumes. Furthermore, it is notable that the greatest uncertainty in the ash mass concentration results from approximating the radius of 
Fig. 7 Ash mass concentration maps $\left(\mathrm{gm}^{-3}\right)$ obtained from the $M 3$ and $M 5$ LiDAR

measurements
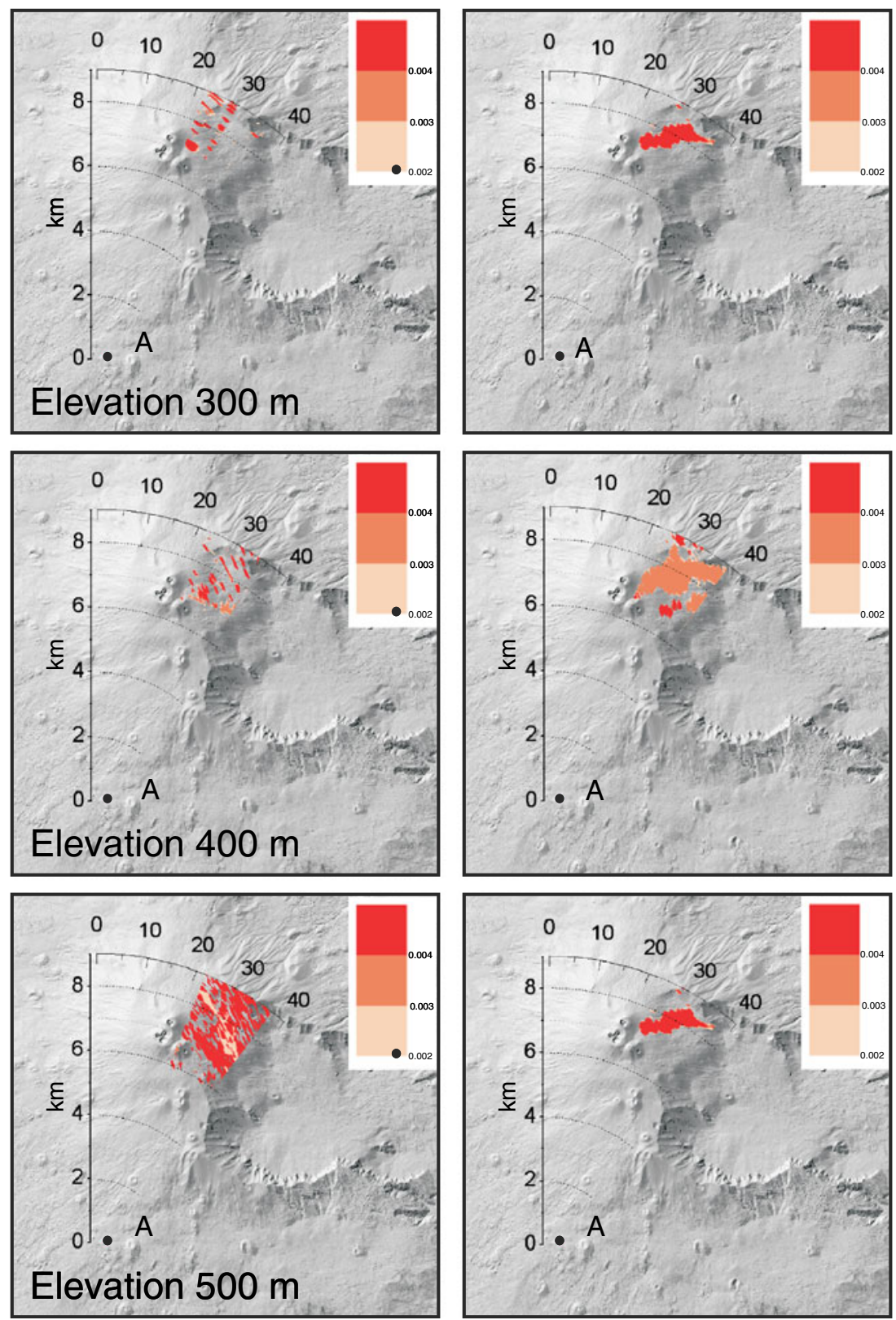

particles in the clouds (Pisani et al. 2012). However, all these limitations could be reduced using more advanced LiDAR systems which include for example measurements of backscattering and extinction at different wavelengths.

In future, LiDAR like the VAMP system could be coupled with satellite data. Although this technique is wellknown in meteorology (e.g. Berthier et al. 2006), there are few studies in Volcanology. Stohl et al. (2011), for example, integrated observations from SEVIRI and LiDAR from the Cloud-Aerosol LiDAR with Orthogonal Polarisation, and dispersion simulations from FLEXPART in order to provide a 3D observational data set. Furthermore, INGV-OE has installed a network of UV spectrometers that allows measuring $\mathrm{SO}_{2}$ fluxes around the volcano in real time and with high frequency (Burton et al. 2004). These data could also be integrated with the LiDAR data in order to evaluate $\mathrm{SO}_{2} /$ volcanic ash ratio which is a key factor to better understand volcanic plume dynamics. The VAMP system, coupled with other instruments already installed at INGV-OE, will hence provide complementary information on volcanic ash dispersal and allow identification of those areas which should be off-limits to aviation operations.

\section{Conclusions}

This work has shown that a scanning elastic LiDAR with depolarization measurement capability may give useful 
support to monitor Etna volcanic plumes. A first preliminary test was carried out on 15 November 2010 when NEC erupted volcanic ash and degassing occurred from BNC. The LiDAR investigated different volcanic plume layers and analysed, when it was pointed in a fixed direction, the frequency of the volcanic explosions. LiDAR was able to distinguish different types of aerosol and may hence help to differentiate ash-dominated from sulphate and/or water dominated plumes. Analysis of the backscattering and depolarisation signals allowed us to evaluate, with a certain degree of uncertainty, the ash mass concentration. For the observed event, values indicating areas with high ash contamination were found only in proximity of the summit craters. Scanning LiDAR routinely used to monitor the volcanic plumes at Etna may help to improve our understanding on the volcanic dispersal and drastically reduce, if used together with volcanic ash dispersal models and other instruments, the risks to aviation operations during the frequent Etna eruptions.

Acknowledgements Volcanological information was obtained by INGV-OE reports of Etna activity. The authors thank Boris Behncke, who furnished information of the Etna activity. The authors also thank the native English speaker Stephen Conway. The authors are grateful to Emilio Biale, Francesco Ciancitto, Michele Prestifilippo and Emilio Pecora who maintain the video-surveillance system at INGV-OE. The authors thank the reviewer Adam Durant, the anonymous reviewer, the associate editor Jacopo Taddeucci and the executive editor James D.L. White for their useful suggestions. This work was funded by the VAMOS SEGURO project, Programma di Cooperazione Transfrontaliera Italia-Malta 2007-2013, A1.2.3-62, Obiettivo Specifico 2.3. The research leading to these results has received funding from the European Union Seventh Framework Programme (FP7/2007-2013) under grant agreement $n^{\circ} 262254$.

\section{References}

Ackermann J (1998) The extinction-to-backscatter ratio of tropospheric aerosol: a numerical study. J Atmos Ocean Technol 15:10431050

Alparone S, Andronico D, Sgroi T, Ferrari F, Lodato L, Reitano D (2007) Alert system to mitigate tephra fallout hazards at Mt. Etna Volcano, Italy. Nat Hazards. doi:10.1007/s11069-007-9120-7

Andò B, Pecora E (2006) An advanced video-based system for monitoring active volcanoes. Comput Geosci 32:85-91

Andronico D, Spinetti C, Cristaldi A, Buongiorno MF (2009) Observations of Mt. Etna volcanic ash plumes in 2006: an integrated approach from ground-based and polar satellite NOAA-AVHRR monitoring system. J Volcanol Geotherm Res 180:135-147

Andronico D, Lo Castro D, Sciotto M, Spina L (2012) The 2010 ash emissions at the summit craters of Mt. Etna: relationship with seismo-acoustic signals. In revision on Journ Geophys Res

Ansmann A, Tesche M, Groß S, Freudenthaler V, Seifert P, Hiebsch A, Schmidt J, Wandinger U, Mattis I, Müller D, Wiegner M (2010) The 16 April 2010 major volcanic ash plume over central Europe: EARLINET LIDAR and AERONET photometer observations at Leipzig and Munich, Germany. Geophys Res Lett 37. doi:10.1029/2010GL043809
Ansmann A, Tesche M, Seifert P, Groß S, Freudenthaler V, Apituley A, Wilson KM, Serikov I, Linné H, Heinold B, Hiebsch A, Schnell F, Schmidt J, Mattis I, Wandinger U, Wiegner M (2011) Ash and fine-mode particle mass profiles from EARLINET-AERONET observations over central Europe after the eruptions of the Eyjafjallajökull volcano in 2010. J Geophys Res 116:D00U02. doi:10.1029/2010JD015567

Barsotti S, Andronico D, Neri A, Del Carlo P, Baxter PJ, Aspinall WP, Hincks T (2010) Quantitative assessment of volcanic ash hazards for health and infrastructure at Mt. Etna (Italy) by numerical simulation. J Volcanol Geotherm Res 192(1-2):85-96

Barton IJ, Prata AJ, Watterson IG, Young SA (1992) Identification of Mount Hudson volcanic cloud over SE Australia. Geophys Res Lett 19:1211-1214

Behncke B, Falsaperla S, Pecora E (2009) Complex magma dynamics at Mount Etna revealed by seismic, thermal, and volcanological data. J Geophys Res 114. doi:10.1029/2008JB005882

Berthier S, Chazette P, Couvert P, Pelon J, Dulac F, Thieuleux F, Moulin C, Pain T (2006) Desert dust aerosol columnar properties over ocean and continental Africa from Lidar in-Space Technology Experiment (LITE) and Meteosat synergy. J Geophys Res 111. doi:10.1029/2005JD006999

Blong RJ (1984) Volcanic hazards. A sourcebook on the effects of eruptions. Academic, Sidney

Bonadonna C, Folch A, Loughlin S, Puempel H (2012) Future developments in modelling and monitoring of volcanic ash clouds: outcomes from the first IAVCEI-WMO workshop on Ash Dispersal Forecast and Civil Aviation. Bull Volcanol 74:1-10

Branca S, Del Carlo P (2005) Types of eruptions of Etna volcano AD 1670-2003: implications for short-term eruptive behavior. Bull Volcanol 67:732-742

Burton M, Caltabiano T, Salerno GG, Mure F, Condarelli D (2004) Automatic measurements of SO2 flux on Stromboli and Mt. Etna using a network of scanning UV spectrometers. J Geophys Res 31. doi:10.1029/203GL019181

Carey SN, Sparks RSJ (1986) Quantitative models of the fallout and dispersal of tephra from volcanic eruption columns. Bull Volcanol 48:109-125

Carstea E, Radulescu R, Belegante L, Radu C (2010) Volcanic ash monitoring over Bucharest area using a multiwavelength Raman lidar. Optoelectron Adv Mater Rapid Commun 4:2162-2166

Chester DK, Duncan AM, Guest JE, Kilburn CRJ (1985) Mount Etna, anatomy of a volcano. Stanford University Press, Stanford

Colette A, Favez O, Meleux F, Chiappini L, Haeffelin M, Morille Y, Malherbe L, Papin A, Bessagnet B, Menut L, Leoz E, Rouïl L (2010) Assessing in near real time the impact of the April 2010 Eyjafjallajökull ash plume on air quality. Atmos Environ 45:1217-1221

Corradini S, Tirelli C, Gangale G, Pugnaghi S, Carboni E (2010) Theoretical study on volcanic plume $\mathrm{SO}_{2}$ and ash retrievals using ground TIR camera: sensitivity analysis and retrieval procedure developments. IEEE Trans Geosc Remote Sens 48:1619-1628

Corsaro RA (2010) Rapporto settimanale sull'attività eruttiva dell'Etna (5-11 aprile 2010), Prot. int. $n^{\circ}$ UFVG2010/14, Intenal Report in www.ct.ingv.it

Corsaro RA, Pompilio M (2004) Magma dynamics in the shallow plumbing system of Mt. Etna as recorded by compositional variations in volcanics of recent summit activity (1995-1999). J Volcanol Geotherm Res 137:55-71

Defoor TE, Robinson E, Ryan S (1992) Early LIDAR Observations of the June 1991 Pinatubo eruption plume at Mauna-Loa-Observatory, Hawaii. Geophys Res Lett 19:187-190

Di Grazia G, Cannata A, Montalto P, Patanè D, Privitera E, Zuccarello L, Boschi E (2009) A multiparameter approach to volcano monitoring based on 4D analyses of seismo-volcanic and acoustic 
signals: the $2008 \mathrm{Mt}$. Etna eruption. Geophys Res Lett. doi:10.1029/2009GL039567

Durant A, Bonadonna C, Horwell CJ (2010) Atmospheric and environmental impacts of volcanic particle emissions. Elements 6:235-240

Fernald FG (1984) Analysis of atmospheric lidar observations: some comments. Appl Optics 23:652-653

Fiorani L, Colao F, Palucci A (2009) Measurement of Mount Etna plume by $\mathrm{CO}_{2}$-laser-based lidar. Opt Lett 34:800-802

Folch A, Jorba O, Viramonte J (2008) Volcanic ash forecast-application to the May 2008 Chaiten eruption. Nat Hazards Earth Syst Sci 94:109-117

Gasteiger J, Groß S, Freudenthaler V, Wiegner M (2011) Volcanic ash from Iceland over Munich: mass concentration retrieved from ground-based remote sensing measurements. Atmos Chem Phys 11:2209-2223

Guffanti M, Mayberry GC, Casadevall TJ, Wunderman R (2008) Volcanic hazards to airports. Nat Hazards. doi: 10.1007/s11069-0089254-2

Horwell CJ, Baxter PJ (2006) The respiratory health hazards of volcanic ash: a review for volcanic risk mitigation. Bull Volcanol 69:1-24

Klett JD (1985) Lidar inversion with variable backscatter/extinction ratios. Appl Optics 24:1638-1643

Lacasse C, Karlsdottir S, Larsen G, Soosalu H, Rose WI, Ernst GGJ (2004) Weather radar observations of the Hekla 2000 eruption cloud, Iceland. Bull Volcanol 5:457-473

Larsen G, Vilmundardòttir EG, Thorkelsson B (1992) The 1991 Hekla eruption: ash fall and ash layer from the first days of the eruption. Nàtturufroeingurinn 61(3-4):159-176

Mather TA, Pyle DM, Oppenheimer C (2003) Tropospheric Volcanic Aerosol, in Volcanism and the Earth's Atmosphere, Geophysical Monograph 139, A. Robock and C. Oppenheimer eds., Am. Geophys. Union, Washington, D.C., pp 189-212

Newhall CG, Self S (1982) The volcanic explosivity index (VEI): an estimate of explosive magnitude for historical volcanism. J Geophys Res 87:1231-1238

Oppenheimer C (2003) Volcanic degassing. In: Rudnick RL (ed) The crust, Holland HD, Turekian KK. Treatise on geochemistry, vol 3. Elsevier-Pergamon, Oxford, pp 123-166

Pappalardo G, Amodeo A, Mona L, Pandolfi M, Pergola N, Cuomo V (2004) Raman LIDAR observations of aerosol emitted during the 2002 Etna eruption. Geophys Res Lett 31. doi:10.1029/ 2003GL019073

Pisani G, Boselli A, Coltelli M, Leto G, Pica G, Scollo S, Spinelli N, Wang X (2012) Lidar depolarization measurement of fresh volcanic ash from Mt. Etna, Italy. Atmos Environ 62:34-40

Prata AJ (1989) Infrared radiative transfer calculations for volcanic ash clouds. Geophys Res Lett 16:1293-1296

Robock A (2000) Volcanic eruptions and climate. Rev Geophys 38 (2):191-219

Sassen K (2005) Polarization in lidar. In: Weitkamp C (ed) Lidar. Springer, New York, pp 19-42

Sassen K, Zhu J, Webley P, Dean K, Cobb P (2007) Volcanic ash plume identification using polarization lidar: Augustine eruption, Alaska. Geophys Res Lett 34. doi:10.1029/2006GL027237

Schumann U, Weinzierl B, Reitebuch O, Schlager H, Minikin A, Forster C, Baumann R, Sailer T, Graf K, Mannstein H, Voigt C, Rahm S, Simmet R, Scheibe M, Lichtenstern M, Stock P, Rüba H,
Schäuble D, Tafferner A, Rautenhaus M, Gerz T, Ziereis H, Krautstrunk M, Mallaun C, Gayet JF, Lieke K, Kandler K, Ebert M, Weinbruch S, Stohl A, Gasteiger J, Groß S, Freudenthale V, Wiegner M, Ansmann A, Tesche M, Olafsson H, Sturm K (2011) Airborne observations of the Eyjafjalla volcano ash cloud over Europe during air space closure in April and May 2010. Atmos Chem Phys 11:2245-2279

Scollo S, Coltelli M, Prodi F, Folegani S, Natali S (2005) Terminal settling velocity measurements of volcanic ash during the 2002 2003 Etna eruption by an X-band microwave raingauge disdrometer. Geophys Res Lett 32. doi:10.1029/2004GL022100

Scollo S, Prestifilippo M, Spata G, D’Agostino M, Coltelli M (2009) Forecasting and monitoring Etna volcanic plumes. Nat Hazards Earth Syst Sci 9:1573-1585

Scollo S, Kahn RA, Nelson DL, Coltelli M, Diner DJ, Garay MJ, Realmuto VJ (2012) MISR observation of Etna volcanic plumes. J Geophys Res 117. doi:10.1029/2011JD016625

Sicard M, Rocadenbosch F, Reba MNM, Comeron A, Tomas S, Garcia-Vizcaino D, Batet O, Barrios R, Kumar D, Baldasano JM (2011) Seasonal variability of aerosol optical properties observed by means of a Raman lidar at an EARLINET site over Northeastern Spain. Atmos Chem Phys 11:175-190

Sicard M, Guerrero-Rascado JL, Navas-Guzman F, Preissler J, Molero F, Tomas S, Bravo-Aranda JA, Comeron A, Rocadenbosch F, Wagner F, Pujadas M, Alados-Arboledas L (2012) Monitoring of the Eyjafjallajokull volcanic aerosol plume over the Iberian Peninsula by means of four EARLINET lidar stations. Atmos Chem Phys 12:3115-3130

Sparks RSJ, Bursik MI, Carey SN, Gilbert JS, Glaze LS, Sigurdsson H, Woods AW (1997) Volcanic plumes. Wiley, Chichester

Spina L, Lo Castro D, Sciotto M, Andronico D (2012) Investigation of 2010 ash emission episodes at Mt Etna by combining volcanological and seismo-acoustic analyses. EGU General Assembly 2012, Vol. 14, EGU2012-5534-1

Stohl A, Prata AJ, Eckhardt S, Clarisse L, Durant A, Henne S, Kristiansen NI, Minikin A, Schumann U, Seibert P, Stebel K, Thomas HE, Thorsteinsson T, Torseth K, Weinzierl B (2011) Determination of time- and height-resolved volcanic ash emissions for quantitative ash dispersion modeling: the 2010 Eyjafjallajokull eruption. Atmos Chem Phys Discuss 11(2):5541-5588

Tesche M, Ansmann A, Muller D, Althausen D, Engelmann R, Freudenthaler V, Gro $\beta$ S (2009) Separation of dust and smoke profiles over Cape Verde by using multi-wavelength Raman and polarization lidars during SAMUM 2008. J Geophys Res 114: D13203. doi:10.1029/2009JD011862

Thomas HE, Watson IM (2010) Observations of volcanic emissions from space: current and future perspectives. Nat Hazards 54:323354

Wandinger U (2005) Introduction to Lidar. In: Weitkamp C (ed) Lidar. Springer, New York, pp 19-42

Wang X, Boselli A, D'Avino L, Pisani G, Spinelli N, Amodeo A, Chaikovskyd A, Wiegner M, Nickovi S, Papayannis A, Perrone MR, Rizi V, Sauvage L, Stohl A (2008) Volcanic dust characterization by EARLINET during Etna's eruptions in 2001-2002. Atmos Environ 42:893-905

Winker DM, Osborn MT (1992) Preliminary analysis of observations of the Pinatubo volcanic plume with a polarization-sensitive lidar. Geophys Res Lett 19:171-174 